\title{
Toward a Big History Interpretation of Religion
}

Ken Baskin

Correspondence | Ken Baskin, baskinman47@yahoo.com

Citation | Baskin, K. (2019) Toward a Big History Interpretation of Religion, Journal of Big History, III (4); 147 $-166$.

DOI | https://doi.org/10.22339/jbh.v3i4.3455

Abstract: The word "religion" refers to a wide range of phenomena ranging from Tibetan Buddhism to the Prosperity Gospel. As a result, religion has accrued a "bewildering variety of definitions". This essay, rather than asking the ontological question - "What kind of thing is religion?" - looks at religion epistemologically, asking what religion enables people to know. The resulting exploration suggests that religion is part of the process by which human groups come to know and adapt to the powerful, often-mysterious forces that produce awe and terror. By looking at how societies at different levels of social complexity have responded to the crises produced by these forces, the author suggests that the habits of mind that would become science and philosophy, as well as religion, evolved as the way those societies have adapted to existential crises, especially in times of rapid, widespread change.

Key Words: mental models, myth, ritual, hominin evolution, social complexity

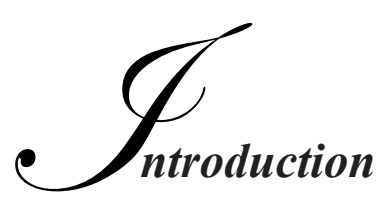

How should students of Big History approach religion? It sounds like a simple question, but little about religion is simple, even defining the word, as Wilfred Cantrell Smith pointed out a half century ago. The word, he notes, had generated "a bewildering variety of definitions" (1991/1962: 17). Among the dozens of definitions and more-general descriptions, religion has been called a "childhood neurosis" (Freud, 1989/1927); an "opiate of the people" (Marx, 1844); a "by-product of the misfiring of several [brain] modules" (Dawkins, 2006: 209); “a meaningful, allpervasive order that embraces the world" (Assmann, 2001: 3); the source of moral behavior (Norenzyan, 2013; Stark, 2011); and a "disease of the human mind" (Russell, 1936). To add to the confusion, nearly all these descriptions seem valid from their author's points of view. However, if most of these descriptions are valid, then the really interesting question is: Can one gather all these fragments of the concept we call "religion" into a coherent, scientifically valid schema? That's the task I want to begin in this essay.
Before I do, however, it's important to take a look at two key problems that have made it so difficult to avoid this fragmentation of and confusion about religion as a concept. First, the dominant Western intellectual model of religion has taught scholars to think of religion in ways that are significantly different from the way people in other times and places have. Consider just three elements:

- Westerners think of religion as a set of beliefs and behaviors that are separate from ordinary life, mostly for the Sabbath and Holy Days (Winzeler, 2012). As satirist Tom Lehrer observes, "On Christmas Day you can't get sore./Your fellow man you must adore./There's time to rob him all the more/The other three hundred and sixty-four" (1959). On the other hand, in most times and places, religion is so deeply woven into everyday life that there isn't even a word for it (Nongbri, 2013).

- Westerners assume that religion demands the individual's belief in the literal truth of 
mythology (e.g., Dennett, 2007). Yet, in other places and times, people were not concerned with whether members of the group believed their gods were true; what was important was participation in group rituals (Vásquez, 2011; Walton, 2006).

- Westerners think of religion as a set of things that act as agents in the world - systems of belief and practice (e.g., Durkheim, 1915), institutions (e.g., Dennett, 2006), and forces for good or evil (e.g., Stark, 2011; Harris, 2004). Until the Reformation, however, Western Europeans thought of religion as an attitude, a sense of inner piety that informed behavior (Harrison, 2015).

This dominant way of thinking doesn't create serious problems for scholars who are examining Western religions today. But when they are exploring the origins of religion, the application of today's atypical understanding to earlier times can drive even a first-class thinker such as Richard Dawkins to make questionable statements, such as his suggestion that religion "doesn't have a direct survival value of its own" (2006: 200), a suggestion I shall contradict repeatedly in this essay.

The second problem is the use of the word "religion". For one thing, the concept of religion was the creation of Western academics to indicate a class of phenomena that may not always fit together comfortably (Smith, 1991/1962). After all, the animism of Australian Aborigines is far different from Catholicism or Islam, and all of them are unlike Buddhism, Hinduism, or Daoism. Moreover, some religions, such as Christianity and Islam, posit a God who seems like a punishing father who exists outside the natural world, while others, such as Hinduism and Buddhism, identify God as the consciousness of which we are part; some religions teach a difficult ascetic path while others seem to function more like social clubs. To put them all together in the same linguistic bucket is to invite misunderstanding. As Smith puts it, "The phenomena that we call religious undoubtedly exist. Yet perhaps the notion that they constitute in themselves some distinctive entity is an unwarranted assumption" (1991/1962: 17). Is it any wonder that so much of the literature about religion - not all, but much - seems fragmented and confusing?

In this paper, I want to present the beginnings of an alternate model of religion avoiding this fragmentation and confusion by exploring religion as part of an evolutionary process. Creating such a model is a task I cannot hope to complete alone. It requires applying research from fields ranging from paleoanthropology and neuroscience to biosemiotics and complexity theory, and I bring only a limited knowledge of any of these fields. My purpose, then, is not to present a finished version of this model. Rather, I want to suggest what this model might be capable of so that others who find it interesting can refine and perfect it.

To develop such a preliminary version of this model, I want to explore five issues:

- Describe religion as an evolutionary process that integrates myth and ritual;

- Provide an overview of the conditions in which religion began to emerge as climate change drove our hominin ancestors from the East African rainforests;

- Speculate how myth developed as those ancestors learned to live in new and changing environments;

- Suggest how the need for stronger social bonds in far more open woodlands and savannahs might have led to proto-religious rituals and their integration with myth;

- Examine how religion can be treated as a wider process, which I call societal adaptive learning. 
With all this in mind, let's begin with the hypothesis I intend to develop and examine as an alternative understanding of religion.

\section{A Tentative Description of Religion}

From my point of view, religion uses myth and ritual to enable human groups to know and adapt to the powerful, often mysterious forces that evoke awe and terror. These are the "powerful forces that permeate things but cannot ordinarily be seen" (Hayden, 2003: 57), the forces that generate birth and death, abundance and famine, the feeling of oneness with the Universe or the experience of being conquered and exiled. Religion has persisted for tens of thousands of years and continues to be universal in human societies, in spite of being costly in terms of time and energy, because it enabled our ancestors to struggle with these powerful forces, adapting to them in ways that produce all the "things" we think of as "religious" - priests, prayers, and rituals; theology, houses of worship, and religious hierarchies. All this suggests that religion enabled its practitioners to survive better than non-practitioners (Hayden, 2019).

While my focus is on human religion, like most evolutionary developments (Schwartz, 1999), human religion did not appear suddenly. Rather, a significant body of evidence suggests that the practices and feelings we associate with religion are deeply grounded in "proto-religious" behaviors, especially among large-brained mammals. Those behaviors include the burial rituals of elephants (Meredith, 2001), the insistence on fair treatment among primates (de Waals, 2014), or signs of proto-religious awe and ritualized behavior among chimpanzees (Turner, et al., 2018). My speculation is that, with changes in brain structure among our hominin ancestors, these proto-religious behaviors and feelings could have evolved over time into what would become a more recognizable human form. With the emergence of Homo erectus, 1.8 million years ago, a larger, more sophisticated brain may have led to early storytelling, and therefore myth- making, capabilities (Laughlin, et al., 1990; Donald, 1991; Newberg, et al., 2001; Everett, 2017)) and a far more corporate, mutually assisting sociality, likely with significant rituals (Turner, et al, 2018). Myth and ritual, I suggest, became increasingly integrated in Neanderthals and, perhaps, archaic Homo sapiens, whose sophisticated language added a powerful element to existing proto-religious behaviors.

What enabled these proto-religious behaviors to become religion, in the sense I am using the word, was the way the human brain structures conscious experience around a symbolic order. Scholars continue to argue over when this symbolic capability developed, ${ }^{1}$ but dating its emergence seems far less important than the fact that human beings do order their perceptions of the world symbolically. In religion, elements of this symbolic order include what Roy Rappaport (1999) calls "Ultimate Sacred Postulates", cosmological axioms that cannot be proven, but are accepted as obviously true. In Judaism, the Shema, declaring the oneness and uniqueness of the Hebrew God, is such a cosmological axiom, as is the Nicene Creed in Christianity. Even the Newtonian worldview is symbolically ordered around cosmological axioms, such as the belief that the Universe is composed of separate, distinct things, or that it exists in four dimensions. I speculate that once the biological drive to tell stories about events around us (Laughlin, et al., 1990) and the hominin adaptation of primate ritualized behavior came together with the symbolic ordering of experience and mutually dependent social relationships, religion would have become all but inevitable.

Turning now to the climate change that drove our evolutionary ancestors out of the East African rainforests, perhaps five million years ago.

\footnotetext{
1 These estimates range from Robin Dunbar's (2016)30,000 years to my personal favorite, Brian Fagan's (2010) 70,000 years, and Merlin Donald's (1991) 125,000.
} 


\section{Out of the Rainforests}

By five million years ago, climate change had dried out parts of the East African rainforests, eventually driving our evolutionary ancestors - the hominins ${ }^{2}-$ down from the trees and into woodlands and savannahs (Fagan, 2004). That was a bold move that must have been made under terrible stress (Hayden, 2003). For more than 20 million years their ancestors, the great apes, had lived in those rainforests and evolved to meet its challenges, developing instincts and habits to deal with most of the experiences that threatened their survival. But now, the hominins were living in environments in which they had little experience. And because rapid climate change was continuing, the savannah they inhabited might shift to woodlands or even deserts, in the lifetime of any of those hominins (Fagan, 2010).

Given these conditions, they would face two key survival challenges. First, compared to their ancestors, they were strangers in strange lands and had not evolved to adapt to their new conditions. As a result, they faced new and unexpected dangers. The woodlands and savannahs they now inhabited had more scattered water supplies, and their plant foods were lower nutritive quality. As a result, they had to become more mobile and began eating meat, when it was available, more often (Fagan, 2004). To survive, they would almost certainly have had to evolve to have more memory and be more adventurous and innovative, developing new ways of perceiving the world that would allow them to take advantage of their new opportunities and avoid new threats.

These hominins would also need to cooperate more intensely. In the rainforests, the great apes lived in ample foliage, making it relatively easy

2 "Hominin" generally describes the evolutionary family of primates that separated, first, from the great apes of East Africa and, then, from the common ancestor of humans, chimpanzees, and bonobos. Its members may include australopithecines, Homo erectus, Neanderthals and Homo sapiens. to hide from predators, and allowing them to live relatively individualistic lives, with only a few close relationships (Turner, et al., 2018). Our hominin ancestors, however, lived largely on savannahs, in which they were far more exposed. So, as Robin Dunbar notes, "large social groups would . . . have been their main defence against predators on open pans and flood plains" (2016: 127). In addition, they would need to cooperate in order to scavenge and hunt for meat (Everett, 2017). As a result, they likely evolved to develop closer emotional ties and more intensely social groups.

The first of these challenges, as examined below, would lead to the ability to make myth; the second, to rituals. My basic assumption is that meeting both of these challenges was a matter of survival. There's been a great deal of discussion in scholarly literature about whether ritual or myth came first (e.g., Segal, 2015). I won't enter this debate. I find it far more important that these two adaptations to very different survival challenges did come together, and, in doing so, created such a powerful process for adaptation.

\section{Rise of the Mythmaking Hominin}

Our hominin ancestors would meet the first of these challenges in new and dangerous environments by entering an evolutionary path that would lead their descendants to become mythmakers. To present that path more clearly, I've broken my discussion into two sub-sections: First a look at the universal need of living things to know what they need to know in order to survive and how the human brain evolved in response to this need; then, an examination of the three questions the human brain must answer when faced with the powerful forces that led to mythmaking. I want to emphasize that many of the specifics that follow are speculative, based on the best available science.

\section{Modeling reality}

One challenge our hominin ancestors faced is 


\begin{tabular}{|c|c|c|c|}
\hline \multirow{5}{*}{$\begin{array}{l}\text { universal. } \\
\text { every species that } \\
\text { evolved since life } \\
\text { first appeared on } \\
\text { Earth about four } \\
\text { million years ago, }\end{array}$} & Species & Estimated Cranial Size & Date \\
\hline & Chimpanzee & $350 \mathrm{cc}$ & c. 5 million years ago \\
\hline & Australopithecus africanus & $400 \mathrm{cc}$ & c. 3.5 million years ago \\
\hline & Homo erectus & $850 \mathrm{cc}$ & c. 1.8 million years ago \\
\hline & Homo sapiens & $1350 \mathrm{cc}$ & c. 250,000 years ago \\
\hline
\end{tabular}

they had to evolve ways to know those things essential to

Table 1: Evolution of the Human Brain (Sarmiento, et al., 2007)

their survival. This challenge is universal because the world-as-it-is - that is, the world before our perception reduces it to manageable dimensions - is overwhelmingly abundant, a buzzing, formless mass of signals (James, 1950/1890), a field of many possible meanings that must be interpreted. In terms of sensual signals, a great deal more is going on in the world we walk through than what we consciously perceive. For example, a dog's sense of smell is thousands of times sharper than ours (Tyson, 2012). How might our perceptions of the world shift if we could smell as dogs do? Given the limited number of sensing organs any organism develops, no living thing can sense more than a "tiny subset of the real patterns in the world" (Dennett, 2017: 128). Members of any species can survive because natural selection has chosen the body structures that will enable them to perceive those patterns they need to recognize.

As a result, every species has had to reduce the field of possibly meaningful patterns into a perceived reality that will enable its members to survive (e.g., Hoffmeyer, 2008). Several thinkers have analyzed this need to reduce the world-as-it-is to a manageable scale. In his pioneering work, Jacob von Uexküll (2010/1934) called an animal's reduced field of perception its Umwelt - that is, the inner, subjective world. More recently, the Biogenetic Structuralists, most notably Charles Laughlin and Eugene d'Aquili, examined how our brains are structured to reduce the "operational environment" of the world-as-it-is to the individual's "cognized environment" (1974). I'll refer to this reduced field of continually changing images as our "perceptual model" of the world.

Any animal's perceptual model, then, enables it to experience the world as "a user-illusion brilliantly designed by evolution to fit [its] needs" (Dennett, 2017: 222). With many species of bat, for example, the perceptual model depends mostly on echolocation sending out ultrasonic sound and creating a perceptual model of the environment from the echoes. Some mammals take advantage of a variety of senses to create their perceptual models. Dogs rely mostly on smell, but also on hearing and sight.

As they moved onto the woodlands and savannahs, our hominin ancestors would live a nomadic life in environments where food and water were more scattered and the environment was subject to change. One key evolutionary change that would enable their descendants to survive was a larger, more sophisticated brain (Table 1). The majority of that growth occurred in the neo-cortex and associated areas such as the hippocampus. This evolving hominin brain gave our ancestors increased memory, enhanced ability to understand the environment, and improved ability to plan and solve problems with its more powerful executive functions. ${ }^{3}$ The larger brains of the australopithecines and Homo erectus were clearly evolving toward the more sophisticated perceptual model that culminated in Homo sapiens. That is, the brains of our evolutionary ancestors seemed to move toward the characteristic human perceptual model, transforming the superabundant world-as-it-is buzzing around them into coherent, story-like models

3 For a fuller discussion of the executive functions, see Donald, 2001. 
(Laughlin, et al., 1990; Gazziniga, 2011).

Here, I use the word "story" in a specific way. Any story must reduce a fictional or real world of events and details into a coherent, meaningful structure (Boje, 2001). That's how people use the word when they ask a friend to give them the "real story" or a TV reporter tells viewers to stay tuned for the "whole story". That's also largely what our brains do at an unconscious level as they create the conscious images of the world that we experience. Neurobiologist Michael Gazzaniga (2011) describes this process as creating "make-sense stories".

Current paleoanthropology suggests that Homo erectus had a brain structure with the memory and problem-solving capability that might have supported an early version of the human, story-creating brain (Turner, et al., 2018; Donald, 1991; Laughlin and d'Aquili, 1974). I find that plausible. After all, Homo erectus migrated across Eurasia, adapting to both the Ice-Age forests of Europe and the jungles of India, and crossing significant bodies of water. The ability to make story-like models and plan more carefully would have made it far simpler to achieve these accomplishments, especially in what appear to be voyages of exploration to Crete, Flores in Indonesia, and Socotra, which is 150 miles from nearest land, the Horn of Africa (Everett, 2017). While other animals have made similar migrations, only humans had to create sophisticated artifacts, such as boats, to complete them.

It's tempting to speculate on when myth-making began to emerge. Bellah notes, for instance, that "something like religion might have developed" with Homo erectus and its increased memory and problemsolving ability (2011: xiv; see also Laughlin and d'Aquili, 1974; Donald, 1991; Newberg, et al., 2001). Laughlin and d'Aquili (1974), Bellah (2011), and Daniel Everett (2017) all take this argument one step further, suggesting that primitive language emerged with Homo erectus, which would have also made some form of verbal myth possible. However, because there simply is no way to verify such speculation, it's enough to note that the brain structures that enabled human religion were well developed by Homo erectus and that they would become more sophisticated, especially with the emergence of Neanderthals and archaic Homo sapiens, as natural selection continued to refine what would become the human story-creating brain.

Current neurobiology indicates today's Homo sapiens story-creating brain works like this: Faced with a new experience, the unconscious mind of any individual integrates a mélange of sense impression and memory and examines it all in light of existing mental models that encode our meaning structures. Then, it filters out any information that doesn't fit the meaning structures, creating a series of possible explanatory stories for any event. Finally, it settles on the scenario that seems most likely to ensure survival and delivers it to the conscious mind. All this happens in a fraction of a second (see Gazzaniga, 2011; Ramachandran, 2011). What makes this unique to human beings, as opposed, say, to the strategic behavior of carnivores such as tigers, is the way human mental models are symbolically coherent and are shaped by shared meaning structures, not just immediate survival needs.

Please note the difference between "perceptual model" and "mental model". A person's perceptual model is the parade of conscious images, which presents a simplified version of the superabundant world-as-it-is, so that he or she can act. When I look down a street here in Philadelphia, my unconscious mind filters out much of what is there so that I can see those things I need to survive. Mental models, on the other hand, present "inner mental replica[s] that [have] the same 'relation-structure' as the phenomenon that [they represent]" (Johnson-Laird, 1983: 11). Such models embody what any person learns that the world should or should not be like. 
They reflect repeated experiences and thereby encode prejudgments about the world, as shaped by the symbolic order that the person accepts. What sort of people should I be afraid of? How should I respond to the U.S. flag? Should I trust people in authority, such as doctors and politicians? What sort of person should I fall in love with? These are some of the questions that anyone's mental models will answer. These models are enormously powerful because they enable us to "filter our ongoing perceptions and prejudge our experiences" (Siegel, 2010: 152), strongly shaping our perceptual models.

\section{Three questions}

With this process, the individual's unconscious mind creates its story-like perceptual model, which enables him or her to understand, consciously, what is going on. To do so, the unconscious mind must answer three critical questions:

1) What's happening?

2) How should I respond?

3) Why is it happening?

Whether confronting a lion on the savannahs of Kenya or a pedestrian darting out into traffic in London, the brain answers the first two questions almost instantaneously in the amygdala, which is intimately connected to memory, below the conscious level. The resulting perceptual models enable us to choose to fight or run away from the lion, or to stop suddenly for the pedestrian. People who can't answer these questions in a way that lets them succeed in the world are less likely to survive (Laughlin, et al., 1990). Once again, the lion confronting a human likely has to answer the same questions; the human brain, however, will focus more intensely of the meaning structure encoded in its mental models.

The brain processes the third question a fraction of a second later, also in the amygdala. Anyone who's known a three-year old has experienced the terrible urgency of the word "why". The answers to this third question often contribute to the mental models that help determine a person's perceptual models, as the answer to "why" becomes effective in interpreting the world - that is, shaping the answers to the first two questions. Any person's mental models will also filter information that conflicts with a model out of that person's perceptual model, as the person tries to make sense out of a confusingly abundant world.

These questions can also be applied socially. When groups are faced with events that evoke awe or terror - a flood, for example, or an especially abundant harvest, their members will work together to answer these three questions: What is the nature of this event? How can they, as a group, best respond to it now and in the future? And what caused this event? I speculate that one source of religion was the cause-and-effect stories, mythic stories, that people have told to answer this third question since Homo sapiens developed the ability to perceive in a symbolically coherent way. Such mythic stories identify the forces of nature that create such events as spirits, ancestors, gods, or the One God, and may also record how they or their ancestors responded. The stories that enabled groups to survive these events most successfully were most likely to enter the group's mythology. What enabled those stories to work is the way that they provided metaphors for the forces of nature that caused the events, opening group members to ways of thinking about the events and creating shared memories about how the group had responded to them in the past (Campbell, 2004; Assmann, 2011). In this way, myth became an early human method for knowing about the natural forces that might pose existential threats and for surviving in a changing, often dangerous world.

This is my central objection to Atran's position (2002) that the mythical world is "supernatural" and "counterfactual". Yes, as Hayden (2018) speculates, many people almost certainly did believe their mythical gods and spirits were real. However, for any society as a whole, especially pre-literate societies, that mythological world could have created a way to 
explain, explore, and adapt to forces that were very real parts of their natural world. Poseidon represented the potentially overwhelming dangers of the sea, to which the seafaring Ancient Greeks had to respond. His presence in Greek mythology could remind people not only of its dangers, but also how others had met them, as in Homer's Odyssey, for example. Especially for pre-literate societies, the metaphor of gods or spirits was an effective way to understand they mysterious. If this analysis is accurate, myth is not merely a collection of "counterfactual" stories; it is often an essential guide to living successfully in the here and now (see Rue, 2005). Myth, and the ritual that brought groups together to remember and celebrate them, may well be how humans first came to know and adapt to such forces.

The importance of these mythic stories has recently been emphasized by the work of neurobiologists such as Andrew Newberg (2018) in the field of study he calls Neurotheology. By scanning the brains of people engaged in religious and spiritual activities such as prayer and meditation, Newberg and his associates have identified several brain circuits that allow people to experience God/gods, as existing in the world and open to relationships (Newberg and Waldman, 2009: 43). The issue here is not whether such circuits "prove" that God is real. Rather, it indicates the importance of being able to experience God/gods as immediate and real. From my perspective, the issue here is the need to be able to use the socially defined concept of God/gods as an exercise in social learning. One's conception of God/gods is the gateway to a variety of types of information about the forces that all of us have to confront, both individually and in groups (Campbell, 2004).

To understand how complex and pervasive religion as a process became, especially as human communities grew larger than hunter-gatherer bands, consider a few of the functions of myth, as people face powerful forces that could overwhelm them:
- First, it offers examples of how we can live our lives in harmony with those forces. On one hand, that means reconciling people to the very real horrors of life, including the realization that life lives on death (Campbell, 2004). In more mundane matters, Judaism gives us the graciousness to strangers of Abraham; Islam, the example of Mohammed as a just ruler; and Hinduism, Arjuna, the soldier caught between his duties as a soldier and the horror of having to fight friends and relatives.

- Second, it provides the stories that encode any culture's symbolic order, to which its young must be socialized (Luckmann, 1967). That symbolic order, encoded in myth, gives members the meaning structure that allows them to interpret the world similarly, to communicate, and to cooperate.

- Third, myth and the symbolic order it encodes enable people to shape their personal identities and recognize other group members from their behavior (Luckmann, 1967). The power of defining "Us" and "Them" through myth and a symbolic order is painfully clear today in the many nationalistic political parties taking power across the globe. Those parties may not be religious, but they use the tools that religion forged.

Moreover, as Jan Assmann notes, "We are what we remember" (2018: 75). The stories of myth give us easy-to-remember examples of much of what we must know to survive in complex social groups as the highly social animals that we are, especially when those myths are enacted in ritual. In fact, until the Axial Age, myth and ritual were one of the most powerful ways for societies to store collective knowledge (Assmann, 2011). This sort of mythic memory is essential to human identity. Americans whose "personal" mythology pictures the Civil War as an example of heroic loyalty and faith in the Southern way of life will understand their identities very differently from 
those whose personal mythology insists the war was the last gasp of American slavery. As a result of this sort of mythic memory, we can create a shared past and memory of our collective triumphs and humiliations, as well as the disasters that might lie ahead, and how we overcame and, in the future, can overcome them.

Finally, when circumstances change enough, the mythic tradition that enabled a society to thrive can begin to destroy it. At that point, people in that tradition must change it, if their society is to survive. This is essentially what happened in Israel after the destruction of the Temple in Jerusalem in 587 BCE. When the Babylonians took the elite of Israelite society into exile, and it seemed that their God, YHVH, had abandoned them, the culture was on the verge of collapse. To ward off that collapse, some members of the elite rewrote the Israelite mythology as a new sacred text that explained how the Israelite people had actually abandoned their God. The text promised that if they worshipped their God as the one true God, He would return His people to glory. With this reinterpreted myth, the Israelite culture would again thrive, as the basis for both Rabbinic Judaism and Christianity (Akenson, 2001). This is the process, which Wallace (1966) calls "revitalization movements", by which the old ways of living and governing society, grounded in its symbolic order, break down, so that society can evolve its myths to respond to new conditions or face its end (see also Assmann, 2011). It also reflects the way elites use religion to manipulate people in the societies they control (Hayden, 2018).

One last thing: People who engage these mythic capabilities can be driven either by communityoriented motives, such as love, or selfish ones, such as fear and the desire for control. We can see that, for example, in the Christian Bible, which begins with Jesus' preaching love, and ends with Revelations and its reflection of fear. Moreover, the Christianity of Paul is very different from that of Constantine because Paul was spreading the Word while Constantine was governing an empire. One reason there are so many different descriptions of religion is that a ruler and a mystic, a dirt-poor farmer and a wealthy merchant approach the powerful stories of myth from such different perspectives and often have different myths.

These few mythic functions might well be enough to explain why religion is such an important part of being human. But there's more. At the same time our evolutionary ancestors were learning to live in new environments, they also had to learn to meet another survival challenge - to live as intensely social animals.

\section{The puzzle of social cohesion}

Living in the savannah, and coming into frequent contact with large predators, demanded that our hominin ancestors become more intensely social. One survival strategy that would facilitate tighter social cohesion appears to have been ritualized behavior. The roots of that behavior seem to have emerged over the last 150 million years as some animals became more and more dependent on cooperation to survive. These "social animals" range from ants and bees to cockatoos, wolves, and chimpanzees. They often rear their young cooperatively, live with several generations in permanent settings, hunt and defend the group together, and rely on group learning. Social animals also have groups with defined roles and hierarchies. As a result, they need ways to communicate complex messages quickly and effectively and, in some animals, to make public displays of loyalty to ensure group cohesion (d'Aquili, et al., 1979).

Some ritualized behavior is almost entirely a matter of genetic programming. For instance, a butterfly, called the silver-washed fritillary, has a seven-step ritual: The male begins with a first signal, and the female makes a countersignal, through seven steps (d'Aquili , et al., 1979). While this "ritual" is fixed in the butterfly's genes, similar behavior patterns in birds and mammals, with more highly evolved brains, are often partially learned, as with the songs birds in 
some species sing to signal they are members of their specific groups.

The more complex the social group, the more important these ritualized behaviors became. Many mammals, wolves for instance, have highly complex group dynamics. Wolves within a pack can have different temperaments and roles; they cooperate in hunting and have social hierarchies. So, they need ways to communicate complex messages. In one ritualized pattern, the leader parades a bone in front of the pack, then drops it so the rest of the pack can inspect, and then ignore it (d'Aquili, et al., 1979: 845). Through this ritual, the leader can state his claim to leadership, and the other members can acknowledge it. As a result, social animals can communicate complex messages - "I am your leader/follower" or "I am approaching you not to hurt you but to negotiate sex" - without verbal language. They also enable group members to commit to the social hierarchy, as with wolves. Or build trust between members, as with primate grooming and human gossip (Dunbar, 2016). ${ }^{4}$

Most great apes and the species that descended from them are social animals, practicing a variety of ritualized behaviors. Some of those behaviors even suggest proto-religious feelings. Chimpanzees, for example, will gather in groups of about 50, and hoot, scream, and drum on old logs with sticks (Turner, et al., 2018: 110). The common rhythmic movement of this behavior enables the chimps to entrain their nervous systems - that is, to share the same neural patterns - creating a sense of group unity (Newberg, 2018; d'Aquili, et al., 1979). Jane Goodall also describes the "waterfall dance", where chimps stand near a powerful waterfall, apparently transfixed by it, swaying in rhythm and behaving with what seems like human wonder. "Perhaps, after all it is not so ridiculous," she observes, "to speculate as to whether chimpanzees might show precursors of religious

4 For a fuller discussion of the pre-human origins of such "ritual" behavior, see d'Aquili, et al., 1979. behaviors" (quoted in Turner, et al., 2018: 114).

Our hominin ancestors had to become far more intensely social and dependent upon each other than chimpanzees. They had to do so because when they left the rainforests of East Africa, they moved into more dangerous environments. When they hunted or scavenged, they needed to protect each other from the large, dangerous predators of the savannah. To strengthen that cooperation, natural selection chose a wider palette of emotions, including key social emotions such as guilt and shame, starting about 3 million years ago, which may have become the "biologically-based propensities for human reliance on religion" (Turner, et al., 2018: 2). The changes in brain structure that resulted in these new emotions appear to also have made a suite of characteristics that we think of as human possible, including affection, responsibility, and the need for belonging (Hayden, 1993). With this wider palette of emotions, our hominin ancestors would likely have adapted primate ritualized behavior to develop proto-rituals that would have become more sophisticated with the emergence of new species, especially Neanderthals (Hayden, 2003). By the time Homo sapiens emerged, their coherent symbolic perceptual model would likely have allowed the sort of ritual that we recognize today.

Like the word "religion", the word "ritual" can be more than a little confusing. There are informal rituals, such as shaking hands; social rituals, such as a Japanese tea ceremony; political rituals, such as the Presidential Inauguration in the U.S.; and religious rituals, such as Catholic Mass or hunter-gatherer initiation ceremonies. While I want to focus on formal, religious rituals, it's worth noting that all rituals have important similarities. All of them enable participants to communicate complex messages, draw tentative conclusions about other participants, and, most important, create a sense of unity among participants (Rappaport, 1999; d'Aquili, et al., 1979). 
For more than a century, scholars have argued over whether myth or ritual came first in the evolution of religion (e.g., Bell, 1997; Segal, 2015). However, for the model of religion examined in this paper, the important issue is not which came first, but the power that resulted from myth and ritual becoming integrated in religion. Those religious rituals have generally become less emotionally intense and more cerebral over the last five or six thousand years, as larger, more complex societies developed strongly institutional religions in which priests replace shamans (Hayden, 2003). In hunter-gatherer and tribal societies, religious rituals evoked more primal emotions, often creating an ecstatic state by inflicting pain, the use of psychotropic drugs, or prolonged drumming, chanting, and dancing (Campbell, 1969). Much of this ritual behavior could lead to altered states of consciousness and mystical visions. Current neuroscience has examined how this ritual can also lead to a feeling of unity among participants, as those rituals enable them to resolve problems of "life and death, good and evil, quest and attainment, God and human being, that are present in mythic form" (d'Aquili and Newberg, 1999: 100). With the secret societies and ancestor cults of complex hunter-gatherer societies (Hayden, 2018) and, then, the emergence of writing and a professional priesthood in the early agricultural states, however, the intensity of rituals, which might include scarification or human sacrifice, lessened. I would suggest that one reason for this shift is that the powerful forces religion was confronting seems to have moved from facing the raw forces that threatened survival to issues of social control and justification of the state. In any case, even today, ritual can create a powerful sense of unity through passion in events such as Hitler's Nuremberg rallies or the anti-war rallies of the 1960s. Here, the religious nature of the rituals has become something quite different, but the neurobiology still seems to be the same.

Like the myth they often dramatize, rituals serve a variety of functions (Wallace 1966; Rappaport, 1999;
Seligman et al., 2008). For example, participation in a ritual signals a person's commitment to the group and teaches the young what it means to be a member. Rituals can also serve the needs of any group's elite, whether by justifying the inequalities of wealth and power that arose in post-forager societies or by enhancing the strong group loyalties that make it easier to motivate members against those outside it. They are also effective in enculturating the young to what it means to be a member (Luckmann, 1967). Key information communicated to the group through rituals can include: elements of group mythology and cosmology; the potentially overwhelming events group members experienced in the past and how they coped with them; and the power of feeling one with the group.

The last of these functions emphasizes Assmann's "We are what we remember". Rituals that are repeated regularly strengthen the neuronal connections in the brain, significantly strengthening any memory over time, thus giving them more power to shape the lives of participants (Newberg, 2019). Consider the Jewish ritual of the Pesach (Passover) seder. The seder ceremony is an annual discussion of the exodus from Egypt, as summarized by its ritual question, "Why is tonight different from all other nights?" It is different because it is the night set aside to retell the story of the exodus, with participants invited to experience the story as if they were actually leaving Egypt. In many ways, the exodus is the central myth of Judaism, and, in the Torah, God tells His people to remember its events on two occasions. The remembrance of this ritual not only enables Jews to self-identify in participating, but would be periodically re-enacted, as they came into a new land, became successful and then oppressed, and were thrown out. In this way, the seder became a yearly rehearsal for the next cycle (Assmann, 2018).

When myth and ritual came together in religion, they provided ways for people in their societies to remember and enact their symbolic orders, to commit 
to their groups and pass on knowledge of it. And when their worlds change so much that the old symbolic orders no longer work, religion, as a process, has repeatedly made a significant contribution to the process of cultural transformation. In the final section of this paper, I'd like to speculate how religion functions as part of a process I think of as societal adaptive learning, which makes this sort of cultural transformation possible.

\section{Religion, cultural transformation, and soci- etal adaptive learning}

The concept of societal adaptive learning emerged as part of the the work I've done examining religion as a process. It offers a possible dynamic for what Wallace calls "revitalization movements". In his words,

$[R]$ eligious belief and practice always originate in situations of social and cultural stress and are, in fact, an effort on the stressladen to construct a system of dogma, myth, and ritual which are internally coherent as well as true descriptions of a world system and which thus will serve as guides to efficient action. (1966: 30)

As Dmitri Bondarenko and I note, three periods of human history demonstrate this sort of social and religious transformation most intensely:

- The Neolithic Revolution (c. 11,000 years ago to 5,000 years ago), during which human communities underwent the transformation from forager bands, mostly egalitarian, nomadic groups of about 20 without hierarchy; to more sedentary transegalitarian, complex hunter-gatherer societies; to more complex city-states; and, eventually, to early agricultural states, such as Ancient Egypt or Shang China with cities of tens of thousands;

- The Axial Age (c. 800-200 BCE), during which the early agrarian state (c. 3000-800 BCE), with a god-like king, ruling through loyalty among his inner circle, became agrarian empires (200 BCE-1500 CE), as in the Roman Empire or Chinese Dynasties;

- Modernity (c. $1500 \mathrm{CE}$ to the present), during which these empires may become a transnational, global system of national entities (Baskin and Bondarenko, 2014).

During each of these transformational periods, the societies experiencing this revitalization found their older, long-successful social structures breaking down and a new structure breaking forth (Assmann, 2011). However, the process by which these transformations occurred suggests that religion is only one of three habits of mind that human groups employ to make such transformations. Curiously, these three habits of mind suggest a group version of the three questions that human brains are structured to answer for us individually:

- What's happening? To answer this question, group members would have to observe the powerful forces in action, calculate their results if possible, and create a model for them. It would be oversimplifying to identify the group version of answering this question as "science", especially in the eyes of those who insist science must provide "reliable predictions in the form of a mathematical model" (Wootten, 2015:383). Yet, it does suggest the habit of mind, a systematic study of nature, at the heart of a scientific approach.

- How should we respond? As they developed a model of the force's actions, group members, especially those in leadership positions, would be likely to discuss their options for responding to those actions, implement the responses they found optimal, and go back to the first question to observe the results. These discussions seem to provide the habit of mind for what we think of as philosophy today.

- Why is it happening? Here, group members have to find the best ways of explaining forces that are both powerful and in many cases mysterious. 
As noted earlier, until science and philosophy emerged as separate studies, the gods and spirits of myth, as representations of these forces, and the rituals that often enacted them, were effective in both explaining and remembering the effects of such forces. As a result, the need to answer this question on a group level may even be a neurological element in the origin of religion. It is, however, important to remember that the people creating these explanations were generally among the elite and were often politically motivated (Hayden, 2018), as in the choice of the Orthodox Christian Church in canonizing the four gospels and rejecting those of the Gnostics (Akenson, 1999; Pagles, 1979).

Because these three habits of mind inform each other in the process by which societies cope with powerful forces, I have come to think of them cumulatively as the process of societal adaptive learning.

The comparison of myth with science and philosophy has rich tradition, including such figures as J.G. Frazer, Claude Lévi-Strauss, and Karl Popper, in the discussion of science, and Paul Radin and Ernst Cassirer in philosophy. ${ }^{5}$ However, to the best of my knowledge, no one else has suggested that myth, science, and philosophy are three components in the same process. I want to emphasize that even if this speculation is valid, any strict one-to-one examination of these questions to the three methods for responding to powerful forces will be misleading. After all, science often tries to determine how people should respond to these forces, and philosophy sometimes speculates on why they happened. Moreover, as we'll see, religion, science, and philosophy complement and provide feedback for each other. What I am trying to suggest is that religion does not stand alone; rather, it is one of three habits of mind that have enabled our species to cope with forces capable of overwhelming human groups, all of which seem to emerge from the structure of the human brain. This is the sort of provocative

5 For an overview, see Segal, 2015. speculation that I found working with this model of religion can generate.

What seems more certain is that all three types of knowledge were incorporated in religion in preliterate times. Writing emerged at the end of the $4^{\text {th }}$ Century BCE in Sumeria and Egypt; it would continue to be used mostly by the government and commercial interests, only becoming culturally important early in the Axial Age, for instance, in Homer's epics or the early Israelite pre-biblical texts (Assmann, 2011). Because the habit of mind that we think of as science was initially fused with religion, the astronomy of Babylon was performed by its priests (Campbell, 2003), and in Egypt, "science and religion were intermingled" (Mancini, 2004: 31). Similarly, the Egyptian Pyramid Texts, one of the earliest religious text scholars are aware of (dated between 2400 and $2300 \mathrm{BCE}$ ), deal with philosophical questions such as "What is life on earth, how does it relate to time and the interrelationship of all things, what is death, what survives death" (Morrow, 2015: 13)?

Science and philosophy began to develop separately from religion in the Axial Age experiences in Greece, India, and China. In all three cases, these methodologies for understanding the powerful, mysterious forces these societies faced remained deeply interconnected. As an example of that interconnection, I want to examine the Greek Axial Age experience. ${ }^{6}$ Mycenaean civilization had dominated Greece from the $14^{\text {th }}$ Century until the middle of the half of the $12^{\text {th }}$ Century BCE. It was ruled was by kings with strong religious duties (Burkert, 1985) who, as in other early agricultural states, governed through the loyalty of their inner circles. Mycenaean religion was built on the oral mythology that Hesiod and Homer would write down in the late $8^{\text {th }}$ and early $7^{\text {th }}$ Centuries. Mycenaean society seems to have been overwhelmed by a combination

6 The Chinese experience is also well documented. Interested readers can consult Robert Temple's The Genius of China (2007) on its science and Benjamin Schwartz's The World of Thought in Ancient China (1985)on its philosophy. 
of factors that may have included climate change, natural disaster, internal hostilities, external threats or competition, and a degree of social complexity its social/economic structure could no longer support. By the end of the $12^{\text {th }}$ Century, all of Greece had entered a period often referred to as a "dark age" (e.g., Cline, 2014).

The culture and political power of Greece would not begin to flourish again until Greek's Axial Age, which began in the late $8^{\text {th }}$ Century and early $7^{\text {th }}$ Century BCE. At that time, Homer and Hesiod were recording Greece's pre-axial oral mythic tradition in writing. This transformative period seemed to begin with a restatement of Greece's traditional religion, as it had evolved to face the challenges its society faced. Partly as a result, Hesiod's retelling of old myths suggests the overwhelming sense of chaos that people in early Axial Age Greece must have felt, as in the story of Uranus eating his children or the rape of Persephone. Homer's epics present an idealized version of the Bronze Age warrior and his dedication to honor as a way to live in harmony with the chaotic forces represented by the Greek gods (Campbell, 2015).

Myth and the symbolic order it encodes, as noted earlier, can help shape the behavior of people in any society. The writings of Homer are especially interesting in this respect. The Iliad, for instance, presents the small Greek polities, such as Mycenae, Sparta, and Ithaca, feuding like brothers, coming together to meet the challenge to their honor of the enemy in the East, Tory, and returning to their old ways. For about 300 years after the Iliad appeared in writing, the leaders of the most powerful poleis, especially Athens and Sparta, behaved exactly that way, feuding like brothers, until, in 490 and 480 BCE, Persia, an enemy from the East, invaded Greece. Like their counterparts in the Iliad, the Greeks would defeat their enemy, and then return to their brotherly fighting, leading to the devastation of the Peloponnesian Wars (434-404 BCE), reinforcing the earlier fears of chaos expressed in Hesiod.

This century of experiences threatened to overwhelm the more powerful cities throughout Greece. It was also a period of cultural efflorescence, especially in Athens, as Greek society sought to answer the three questions of societal adaptive learning. The Greek tragedies of Aeschylus (c. 525-456 BCE), Sophocles (c. 497-406 BCE), and Euripides (c. 472-406 BCE) explored what had happened, examining the chaos of the time at a religious festival, the Dionysia. These tragedies, moreover, were mostly reinterpretations of the mythology found in Hesiod and Homer. The Orestia, for example, examines the chaos that resulted from the Trojan War, especially Agamemnon's decision to sacrifice his daughter Iphigenia to the goddess Artemis. It was as if the society, as a whole, was saying, "We followed the ways prescribed in the stories of the gods, and what we got was chaos. What happened?" The society, as a whole, was asking the first of the three questions the individual human brain must answer when faced with a challenge.

This effort to answer the first question also took other forms. Even before the shocks of the $5^{\text {th }}$ Century, some Greeks were looking to understand the world in new ways, growing from both the need to predict natural phenomena better in a society that increasingly profited from sea trade and the rejection of Greek myth. Starting with Thales (fl. 585), Greek natural philosophy, combining what we think of as philosophy and science, began by rejecting mythic explanations and looking, instead, for answers in nature, rather than the gods. Later, Pythagoras (fl. mid $6^{\text {th }}$ Century) would find perfect harmony in mathematics, making it the basis of a school of mysticism. Early in the $5^{\text {th }}$ Century, Heraclitus (fl. 500), who saw change as the fundamental reality, and Parmenides (fl. 480), who insisted that change was illogical, argued over the fundamental nature of reality. Later still, Leucippius (fl. 435) and Democritus (fl. 410) proposed that everything in the world was composed of tiny particles, atoms, which 
made the cosmos a lifeless machine (Lindberg, 2007).

All this work to understand the world of Ancient Greece would come together in the philosophy of Plato (427-348/47) and Aristotle (384-322), as a way of examining why these catastrophic events had occurred and how to respond to them. Jeremy Lent (2017) describes the emerging Greek worldview as "the divinity of reason". Having lived through the horrors of the Peloponnesian Wars, Plato proposed that a creative spirit, the Demiurge, had employed mathematics to impose the "order and rationality of the cosmos" on what had been chaos (Lindberg, 2007: 19). The chaos that Greece experienced was the result of people not using their rationality, and, instead, settling for mythic explanations which left them experiencing the "shadows" of the real, as he depicted in the Parable of the Cave in the Republic. Aristotle would then apply Plato's "divine" reason to explore areas ranging from biological diversity to tragedy (Bellah, 2011). The world was rational. Human beings created chaos because they would not allow the divine intellect of the "Unmoved Mover" to guide them.

Ultimately, these Axial Age adaptations were successful, allowing Greek society to meet the challenges of the forces of chaos that had challenged it and reestablish a sense of order. The troops of Alexander the Great would spread its symbolic order, Hellenism, all the way to India. Eventually, Rome and its empire would incorporate this sense of a rationally knowable world, and, through Rome it would influence Christianity and Modernity.

What fascinated Bondarenko and me was the way societal adaptive learning seemed to function so similarly in Modernity. Modernity began in society's response to a series of events that overwhelmed the social stability that had been created in Late Medieval Europe. Those events included the rise of a wealthy merchant class in the $13^{\text {th }}$ and $14^{\text {th }}$ centuries (AbuLughod, 1988); the bubonic plague (1340-1400), which killed off a third of the population in all social classes (McNeill, 1976); and a century and a half of religious wars, culminating in the Thirty Years War (1618-48). What would be needed was a new way of experiencing the world and a social order to replace feudalism, enabling Western society to reassert social order and manage the forces that had generated these events.

This social adaptation would begin as leading thinkers in Western Europe adapted old ideas taken from the religious mythology of the Late Medieval Church. First, both scientists and philosophers would take over the Church's view, beginning in the $12^{\text {th }}$ Century, that nature was the purposeful creation of a loving God, a "second book" from which man could come to know God, as they did from the Bible (e.g., Gaukroger, 2006). This transformational process would also draw on the popular Christian myth of the Quest for the Holy Grail, a series of stories about King Arthur and his knights. In this myth, Arthur's kingdom can only be saved by the heroic efforts of Arthur's knights to find the Holy Grail, from which Jesus drank during the Last Supper. Modernity would transform these exemplars of Medieval devotion, on whom their society's salvation depended, into the great heroes of Modernity, scientists.

Much as Greek tragedy transformed the mythology of Hesiod and Homer, modern philosophy would reinterpret the Late Medieval mythology, especially in the work of Francis Bacon (1561-1626) and René Descartes (1595-1650). Bacon called for "a total reconstruction of science, the arts, and human knowledge" (Gillespie, 2009: 37), in order to know what Nature was and how it worked. He therefore promoted science as a quest by a new type of knight, the scientist, whose job was to torture nature in order to make it reveal its secrets. By discovering nature's hidden powers, these quest knights would master nature for the benefit of man and the salvation of society. Like Bacon, Descartes wanted mankind to 
use science to master an unruly and dangerous world, eliminating want and providing security. To achieve those ends, Descartes wanted to create a science of certainty through mathematics, which would enable the scientist to escape the distortions of the senses. By analyzing complex events in the world into their component elements, he believed that it would be possible to understand the laws by which God moved matter (e.g., Gaukroger, 2006). This would be possible because Descartes believed in a loving, reasonable God who would never deceive man. As a result, science would be able to fully explain God's world and how to perfect it (Gillespie, 2009). Descartes' philosophy would sit at the heart of the early modern worldview, as a way to return order to a world society that had descended into the chaos of war and unremitting change.

It was in the intellectual environment in which Descartes' philosophy evolved that Galileo and Newton would demonstrate the power of observing and mathematically modeling the world. Early modern science unfolded from thousands of years of earlier science, some would call it "proto-science" from Ancient Greece, China, India, and Islam (e.g., Lindberg, 2007; Freely, 2012) - creating a backlog of knowledge without which early modern science would have been impossible. In these other societies, the methodology of science - defining what's happening through a systematic study of nature - appears to have been driven, initially, by the need of people in them to adapt significant challenges in nature and society and, also, by the prospects of wealth and power that technology promised.

Early modern science provided a powerful way of addressing the chaos caused by the collapse of feudal social structure and a century-and-a-half of religious war. It promised a way to manipulate a world that had seemed out of control and reorder society rationally. In many ways, Western science has accomplished this, although it has also caused a host of unexpected consequences, from global warming to the possibility of nuclear holocaust. We do live today in a world dominated by the results of science-from the computer I'm writing these words on, to the car I drive, to the pharmaceuticals capable of almost entirely wiping out contagious diseases. In less than 400 years, scientists have made it possible to vastly reduce poverty and the impact of disease. As Wooton notes (2015), science has accelerated the rate of knowledge acquisition by emphasizing the concept of "discovery", in realms that range from sub-atomic particles to the cosmos. In many ways, the early modern worldview culminated in science, just as Axial Age Greece and China tilted their forms of social adaptive learning toward philosophy (Baskin and Bondarenko, 2014). In this way, science would take over more and more of the functions associated with religion, especially after the findings of Lyell in geology and Darwin in evolution made the idea of a world without a God possible.

These summaries of how societal adaptive learning transformed Axial Age Greece and modern Europe are relatively brief. My intent was to make the case for the common origin and ongoing interrelationship between these three habits of mind for more deeply knowing the world. If this speculation is accurate, then it suggests some new avenues for both the study of all religion, science, and philosophy, both as separate phenomena and as complementary parts of societal adaptive learning.

\section{Conclusions}

I want to emphasize that I present this model of religion as a hypothesis, a first step that must be researched, tested, and further developed. Nonetheless, it does seem to possess several advantages, even in its present form. For example, the model offers a narrative to explain why religion can be validly viewed from so many different, sometimes contradictory positions. As we've seen, myth and ritual can serve functions ranging from the personal to the interpersonal to the 
societal. In addition, all these functions can be used for purposes that benefit the community, such as encouraging social cooperation and human kindness, or to increase personal wealth and power, such as enhancing a leader's ability to scapegoat "heretical" groups. As a result, thinkers focusing on one or two functions, enacted from community or personal purposes, can find a wide variety of valid ways of describing religion, ways that may even contradict each other. In this way, religion can be portrayed as a force that can drive both moral behavior (Stark, 2011) and war (Harris, 2004).

Moreover, this model makes it clear why religion is universal to human societies: Religion is the product of millions of years of natural selection choosing for qualities that addressed significant survival challenges: Myth, appears to have emerged with the increasingly more sophisticated brain that enabled our ancestors to perceive the world so that they could behave in more innovative ways in new environments, and human ritual seems to have emerged with the brain changes that enabled them to meet the need for stronger social cohesion. Religion is universal, then, because it combines the evolutionary responses to two critical survival challenges. This is a far more satisfying explanation of religion's universality than Dennett's suggestion (2006) that religion is based on a "Good Trick", an experiment that is rediscovered and found useful, or Dawkins' speculation (2006) that it reflects the misfiring of brain modules. Interpreted through this model, religion is, rather, a key part of how our species has survived.

For me, however, the most important advantage of the model I've been exploring is the way it embeds religion in the complex context of research in fields ranging from neuroanthropology and current evolutionary theory to complexity theory, biosemiotics, and cognitive science (see also William Grassie, 2010). Religion, as I hope I've demonstrated, evolved in response to fundamental challenges to our evolutionary ancestors and has become critical to our cultural survival. As a result, the more fully scholars can understand the nature of being human from a cross-disciplinary position, the better they can expect to understand religion, not merely as systems of belief and practice or as institutions, but as the process by which our species has risen to meet a series of powerful existential challenges. And, in our world today, what sorts of understanding could be more important?

Acknowledgement: I want to express my appreciation for the support I received from so many friends and colleagues. That help was especially important because of the range of disciplines this paper draws on. Among those whom I wanted to acknowledge specifically are my friends - Carl Weisse and Gary Floam - and my colleagues - Brian Spooner, Brian Hayden, Andrew Newberg, and David Blanks. 


\section{References}

Abu-Lughod, J.L. (1989). Before European Hegemony: The World System A.D. 1250-1350, New York: Oxford University Press.

Akenson, D.H. (2001). Surpassing Wonder: The Invention of the Bible and the Talmuds, Chicago, IL: University of Chicago Press.

Assmann, J. (2001). The Search for God in Ancient Egypt, Lorton, D. (trans.), Ithaca, NY: Cornell University Press.

Assmann, J. (2003). The Mind of Egypt: History and Meaning in the Time of the Pharaohs, Jenkins, A. (trans.), Cambridge, MA: Harvard University Press.

Assmann, J. (2011). Culture, Memory, and Early Civilization: Writing, Remembrance, and Political Imagination. Cambridge: Cambridge University Press.

Assmann, J. (2018). The Invention of Religion: Faith and Covenant in the Book of Exodus, Princeton, NJ: Princeton University Press.

Atran, S. (2002). In Gods We Trust: The Evolutionary Landscape of Religion, Oxford: Oxford University Press.

Baskin, K. and Bondarenko, D.M. (2014). The Axial Ages of World History: Lessons for the $21^{\text {st }}$ Century, Litchfield Park, AZ: Emergent Publications.

Bell, C. (1997). Ritual: Perspective and Dimensions, Oxford: Oxford University Press.

Bellah, R.N. (2011). Religion in Human Evolution: From the Paleolithic to the Axial Age, Cambridge, MA: The Belknap Press.

Boje, D.M. (2001). Narrative Methods for Organizational and Communication Research, London: Sage Publications.

Brukert, W. (1985). Greek Religion: Archaic and Classic, Raffan, J. (trans.), Maiden, MA: Blackwell.

Campbell, J. (1969). Primitive Mythology: The Masks of God, New York: Penguin Books.

Campbell, J. (2003). Myths of Light: Eastern Metaphors of the Eternal, Novato, CA: New World Library.

Campbell, J. (2004). Pathways to Bliss: Mythology and Personal Transformation, Novato, CA: New World Library.
Campbell, J. (2015). Romance of the Grail: The Magic and Mystery of Arthurian Myth, Novato, CA: New World Library.

Cline, E.H. (2014). 1777 BC: The Year Civilization Collapsed, Princeton, NJ: Princeton University Press.

D’Aquili, E.G., Laughlin, C.D., and McManus, J., eds. (1979). The Spectrum of Ritual: A Biogenetic Analysis, New York: Columbia University Press.

D'Aquili, E.G. and Newberg, A.B. (1999). The Mystical Mind: Probing the Biology of Religious Experience, Minneapolis, MN: Fortress Press.

Dawkins, R. (2006). The God Delusion, Boston: Mariner Books.

Dennett, D.C. (2006). Breaking the Spell: Religion as a Natural Phenomenon, New York: Penguin Books.

Dennett, D.C. (2017). From Bacteria to Bach and Back: The Evolution of Minds, New York: W.W. Norton \& Co.

DeWaal, F. (2014). The Bonobo and the Atheist: In Search of Humanism Among the Primates, New York: W.W. Norton \& Co.

Donald, M. (1991). Origins of the Mind: Three Stages in the Evolution of Culture and Cognition. Cambridge, MA: Harvard University Press.

Donald, M. (2001). A Mind so Rare: The Evolution of Human Consciousness, New York: W.W. Norton \& Co.

Dunbar, R. (2016). Human Evolution: Our Brains and Behavior, New York: Oxford University Press.

Durkheim, E., (1915). The Elementary Forms of Religious Life, Swain, J.W. (trans.), London: G. Allen \& Unwin.

Everett, D.L. (2017). How Language Began: The Story of Humanity's Greatest Invention, New York: Liverlight Publishing Corp.

Fagan, B.M. (2004). People of the Earth: An Introduction to World Prehistory, $11^{\text {th }}$ ed., Upper Saddle River, NJ: Prentice Hall.

Fagan, B.M. (2010). Cro-magnon: How the Ice Age Gave Birth to the First Modern Humans, New York: Bloomsbury Press.

Freely, J. (2012). Before Galileo: The Birth of Modern Science in Medieval Europe, New York: Overlook Duckworth.

Freud, S. (1989/1927). The Future of an Illusion, New York: W.W. Norton \& Co. 
Gaukroger, S. (2006). The Emergence of a Scientific Culture: Science and the Shaping of Modernity, 1210-1685, Oxford: Clarendon Press.

Gazzaniga, M.S. (2011). Who's in Charge? Free Will and the Science of the Brain, New York: HarperCollins.

Gillespie, M.A. (2009). The Theological Origins of Modernity, Chicago: University of Chicago Press.

Grassie, W. (2010). The New Sciences of Religion: Exploring Spirituality from the Outside In and Bottom Up, New York: Plagrave Macmillan.

Harris, S. (2004). The End of Faith: Religion, Terror, and the Future of Reason. New York: Norton.

Harrison, P. (2015). The Territories of Science and Religion, Chicago: University of Chicago Press.

Hayden, B. (1993). Archaeology: The Science of Once and Future Things, New York: W.H. Freeman and Company.

Hayden, B. (2003). Shamans, Sorcerers, and Saints: A Prehistory of Religion, Washington, D.C.: Smithsonian Books.

Hayden, B. (2018). The Power of Ritual in Prehistory: Secret Societies and Origins of Social Complexity, Cambridge: Cambridge University Press.

Hayden, B. (2019). Email, February 11.

Hoffmeyer, J. (2008). Biosemiotics: An Examination into the Signs of Life and the Life of Signs, Favareau, D. (ed.), Scranton, PA: University of Scranton Press.

James, W. (1950/1890). The Principles of Psychology, New York: Dover Press.

Johnson-Laird, P.N. ((1983). Mental Models: Toward a Cognitive Science of Language, Inference, and Consciousness, Cambridge, MA: Harvard University Press.

Laughlin, C.D. and d'Aquili, E.G. (1974). Biogenetic Structuralism, New York: Columbia University Press.

Laughlin, C.D., McManus, J., and d'Aquili, E.G. (1990). Brain, Symbol \& Experience: Toward a Neurophenomenology of Human Consciousness, Boston, MA: Shambhala Publications.

Lehrer, T. (1959). "A Christmas Carol”, An Evening Wasted with Tom Lehrer, New York: Reprise Records.

Lent, J. (2017). The Patterning Instinct: A Cultural History of Humanity's Search for Meaning, Amherst, NY: Prometheus
Books.

Lindberg, D.C. (2007). The Beginnings of Western Science: The European Scientific Tradition in Philosophical, Religious, and Institutional Context, Prehistory to A.D. 1450, $2^{\text {nd }}$ ed., Chicago, IL: University of Chicago Press.

Luckmann, T. (1967). The Invisible Religion: The Problem of Religion in Modern Society, New York: The Macmillan Company.

Mancini, A. (2004). Maat Revealed: Philosophy of Justice in Ancient Egypt, Buenos Books America.

Marx, K. (1844). A Contribution to the Critique of Hegel's Philosophy of Right, https://www.marxists.org/archive/marx/ works/1843/critique-hpr/intro.htm (accessed, 3/7/18).

McNeil, W.H. (1976). Plagues and Peoples, New York: Anchor Books.

Meredith, M. (2001). Elephant Destiny: Biography of an Endangered Species in Africa, New York: Public Affairs.

Morrow, S.B. (2015). The Dawning Moon of the Mind: Unlocking the Pyramid Texts, New York: Farrar, Straus and Giroux.

Newberg, A. (2018). Neurotheology: How Science Can Enlighten Us about Spirituality, New York: Columbia University Press.

Newberg, A. (2019). Email, February 27.

Newberg, A., d'Aquili, E, and Rause, V. (2001). New York: Ballentine Books.

Newberg, A. and Waldman, M.R. (2009). How God Changes Your Brain: Breakthrough Findings from a Leading Neuroscientist, New York: Ballentine Books.

Nongbri, B. (2013). Before Religion: A History of a Modern Concept, New Haven, CN: Yale University Press.

Norenzayan, A. (2013). Big Gods: How Religion Transformed Cooperation and Conflict, Princeton, NJ: Princeton University Press.

Pagels, E. (1979). The Gnostic Gospels, New York: Vintage Books.

Ramachandran, V.S.(2011). The Tell-tale Brain: ANeuroscientist's Quest for What Makes Us Human, New York: Norton.

Rappaport, R.A. (1999). Ritual and Religion in the Making of Humanity, Cambridge: Cambridge University Press.

Rue, L. (2005). Religion Is Not about God: How Spiritual 
Traditions Nurture Our Biological Nature and What to Expect When They Fail, New Brunswick, NJ: Rutgers University Press.

Russell, B. (1936). Why I Am Not a Christian and Other Essays on Religion and Related Subjects. New York: Simon and Schuster.

Sarmiento, E., Sawyer, G.J., and Milner, R. (2007). The Last Human: A Guide to Twenty- two Species of Extinct Humans, New Haven, CN: Yale University Press.

Schwartz, B.I. (1985). The World of Thought in Ancient China, Cambridge, MA: The Belknap Press.

Schwartz, J.H. (1999). Sudden Oorigins: Fossils, Genes and the Emergence of Species,New York: John Wiley and Sons.

Segal, R.A. 2015. Myth: A Very Short Introduction, 2nd ed., Oxford: Oxford University Press.

Seligman, A.B., Weller, R.P., Puett, M.J., and Simon, B. (2008). Ritual and Its

Consequences: An Essay on the Limits of Sincerity, Oxford: Oxford University Press.

Siegel, D.J. (2010). Mindsight: The New Science of Personal Transformation, New York: Bantam.

Smith, W.C. (1991/1962). The Meaning and End of Religion. Minneapolis, MN:

Fortress Press.

Stark, R. (2011). The Triumph of Christianity: How the Jesus Movement Became the World's Largest Religion, New York: Harper One.

Temple, R. (2007). The Genius of China: 3,000 Years of Science, Discovery and Invention, Rochester, VT: Inner Tradition.

Turner, J.H., Maryanski, A., Petersen, A.K., and Geertz, A.W. (2018). The Emergence and Evolution of Religion: By Means of Natural Selection. New York: Routledge.

Tyson, P., (2012). "Dogs Dazzling Sense of Smell”, https://www. pbs.org/wgbh/nova/article/dogs-sense-of-smell/, (accessed, $12 / 4 / 2017)$

Vásquez, M.A. (2011). More than Belief: A Materialist Theory of Religion, Oxford: Oxford University Press.

Von Uexküll, J. (2010/1934). A Foray into the Worlds of Animals and Humans, O’Neil, J.D. (trans.), Minneapolis, MI: University of Minnesota Press.
Wallace, A.F.C. (1966). Religion: An Anthropological View. New York: Random House.

Walton, J.H. (2006). Ancient Near Eastern Thought and the Old Testament: Introducing the Conceptual World of the Hebrew Bible, Grand Rapids, MI: Baker Academic.

Winzeler, R.L. (2012). Anthropology and Religion: What We Know Think, and Question, Lanham, MD: Altamira Press.

Wotton, D. (2015). The Invention of Science: A New History of the Scientific Revolution, New York: Harper Perennial. 